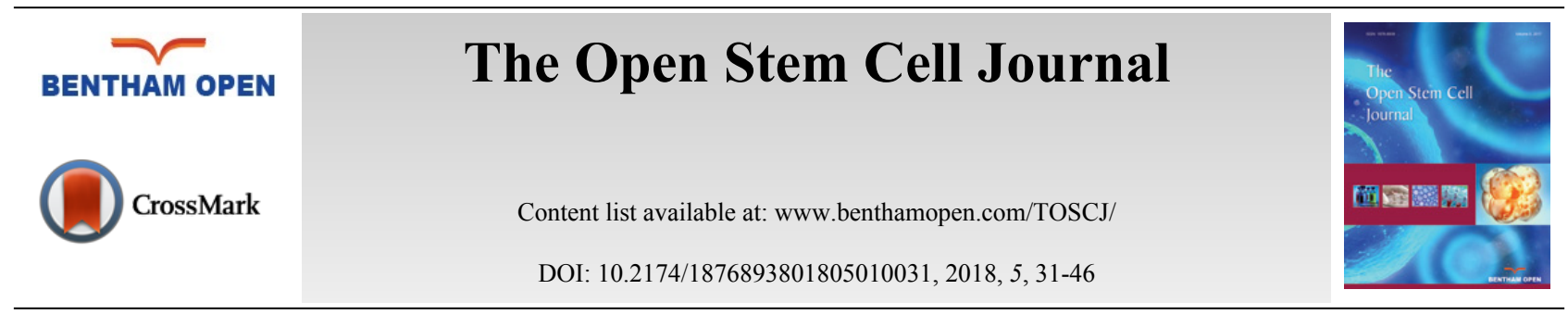

REVIEW ARTICLE

\title{
Ocular Stem Cells to Treat Retinal and Corneal Disorders
}

\author{
Biswa P. Chatterji ${ }^{1, *}$, Godiwala Mehvash ${ }^{2}$ and Sunder Roma ${ }^{2}$

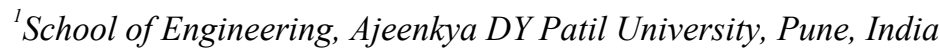 \\ ${ }^{2}$ Department of Biotechnology, St.Xavier's College, Mumbai, India
}

Received: July 17, 2018

Revised: October 12, 2018

Accepted: October 18, 2018

\begin{abstract}
:
Background:

According to WHO, 285 million people are visually impaired out of which, 39 million are classified as blind and the remaining 246 million people have low vision which comprises of moderate vision impairment and severe vision impairment. Therapies to treat major disorders leading to visual impairment like Age-related Macular Degeneration (AMD), Stargardt's Disease (STGD), Retinitis Pigmentosa (RP) and corneal scarring are required.

In the last decade, many advances have been made to treat these disorders using stem cell therapy. For corneal damage by accidental burns, scarring or limbal stem cell deficiencies which can lead to partial or total blindness, are treated with a risky intervention like keratoplasty. To overcome issues like graft rejection caused by keratoplasty as well as have a better outcome, limbal stem cell therapy has been introduced. Similarly, Retinal Pigment Epithelium (RPE) is a supporting tissue essential in nutrient transport, production of growth factors, phagocytosis of the photoreceptors and retinol cycling.
\end{abstract}

\section{Discussion and Conlusion:}

Degeneration of this monolayer causes many diseases that have no prevailing treatment; however, research is being carried out to replace this simple epithelial monolayer primarily with an autologous source of cells and currently using stem cells. This review discusses the advances made in the field of ocular stem cell therapy with regards to development, cultivation and novel methods used to deliver these cells to replace the corneal and retinal epithelium as a new standard for treatment.

Keywords: Cornea, Retina, Retinal pigment epithelium, Corneal stem cells, Retinal stem cells, Limbal stem cells, Keratoplasty, Stem cell therapy.

\section{INTRODUCTION}

According to WHO, 285 million people are visually impaired out of which 39 million are classified as blind and the remaining 246 million people have a low vision which comprises of moderate vision impairment to severe vision impairment [1].

Blindness is primarily caused by the loss of supportive glia which is due to the reduction in neurons. The retina is a part of the central nervous system which shares its regenerative abilities with the brain and spinal tissues thus there are no techniques to transplant lost Retinal Ganglion Cells (RGC) and photoreceptor cells, similarly, axogenic or neuroprotective techniques are unavailable [2]. Retinal Pigment Epithelium (RPE) is a supporting tissue essential in nutrient transport, production of growth factors, phagocytosis of the photoreceptors and retinol cycling. Degeneration of this monolayer leads to diseases like Age-related Macular Degeneration (AMD), Stargardt's disease, Retinitis Pigmentosa (RP) which ultimately cause loss of vision. There are no present remedial treatments for these conditions; however, a great deal of research is being carried out to replace this simple epithelial monolayer primarily with an

\footnotetext{
* Address correspondence to this author at the School of Engineering, Ajeenkya DY Patil University, Pune, India; Tel: +91-9920010371; E-mail: biswaprasun@gmail.com
} 
autologous source of cells predominantly using stem cells [3].

Cornea, a translucent layer concealing the eye serves a vital function of channelling light towards the retina. Corneal scarring that leads to corneal opacity is the major cause of visual impairment; that can be treated by corneal transplantation (keratoplasty) [4]. The corneal surface is comprised of five layers within which the corneal epithelium forms $10 \%$ of the layer that is replenished by stem cells, located at the limbus region of cornea [4, 5]. The remaining $90 \%$ of layer of the corneal surface is composed of stroma which largely consists of water, collagens and keratocytes or quiescent fibroblasts [5].

The cornea has an essential role during the occurrence of wounds and the generation of tear. The presence of corneal nerve is responsible for the sensation of pain and touch. Therefore, any dysfunction of cornea can lead to blindness, where corneal opacity is considered to be the second most causative agent for blindness [6].

Chemical burns that are alkali or acid burn can lead to damage in cornea. The damaged cornea is unable to regenerate causing partial or total blindness. Stevens-Johnson Syndrome (SJS) of the eye may have rare incidence but its severity is high. In this syndrome, continuous as well as increased inflammation and fibrosis of the cornea, causes opacity and a deficiency of stem cell in the affected region eventually evoking to blindness. A study in US from 2010 to 2012 reported incidence of 3834 people suffering from SJS. Considering this incidence rate in the US, it can be expected that approximately 86,500 new cases of SJS are registered every year in the world. Similarly, chemical burn incidents were calculated using the US figure which suggest down to 357,710 burn accidents all over the world [7].

Corneal blindness caused by chemical burns, SJS etc. can be the initiating event for total or partial corneal and/or limbal stem cell deficiency which is frequently treated with keratoplasty. Apart from the difficulty in finding an appropriate donor, a post-surgery complication of allograft rejection is often observed due to corneal vascularization, retinal disease, diabetes, adherent leukemia and bilateral blindness [8]. Thus to attain successful transplantation of cornea and regain its functions, new techniques of cultivation and application of stem cells have been increasing worldwide.

This article briefly summarizes the arising new techniques to combat corneal and retinal blindness. A detailed discussion of all the diseases and conditions leading to visual impairment is outside the scope of the current review and thus we focus on age-related macular degeneration, Retinitis Pigmentosa, Stargardt's Disease and corneal degeneration. These are the preliminary targets for stem cell therapy, therefore we focus on treatments wherein stem cells are cultured and utilized to treat these disorders in the below review. The paper contains tables which help us summarise the patents more efficiently. The patents used herein have been obtained from the World intellectual property organization, Espacenet and Google patents.

\subsection{Age-related Macular Degeneration}

Age-related Macular Degeneration (AMD) is categorised as the primary cause of blindness affecting people above the age of 55 years and it is estimated to infringe 196 million people worldwide by the year 2020 [9]. AMD can be labelled as wet AMD (neovascular choroidal) accounting for 10-15\% of the cases and dry AMD (geographic atrophy) computing for $80-85 \%$ of the total cases [3, 10]. RPE cells are situated below the photoreceptors which perform essential functions as mentioned earlier; these cells are majorly affected by AMD, making it a complex degenerative disease caused as a result of a low-grade inflammation in the retina leading to deterioration of RPE and Bruch's membrane. RPE is involved in phagocytosis of photoreceptor outer segments (OS) disc; overtime the RPE degenerates due to senescence and incomplete digestion of phagosome activating the accumulation of lipofuscin which interferes with RPE functioning and ultimately causing apoptosis. Between the ages of 10-90 years, the Bruch's membrane undergoes thickening bringing about the defect in nutrient transport weakening the RPE to adhere to the basement membrane [3, 11]. Conventional treatment for wet AMD involves the intravitreal injection of Anti-Vascular Endothelial Growth Factor (VEGF) but on discontinuation of the treatment, relapse is observed. The other treatments that are practised includes photodynamic therapy and laser photocoagulation. Although the success rate is low as the RPE cells are previously damaged and surgery might lead to the further removal of healthy cells [12]. Stem cell therapy is a potential treatment for AMD as it can persuade improvement of visual perception [10].

\subsection{Retinitis Pigmentosa}

Retinitis Pigmentosa (RP) is an inherited retinal disorder that can have X-linked, dominant or recessive pattern of inheritance. It is a rare genetic disorder characterised by 100 defined mutations that cause the defect in the 
photoreceptor cells. These mutations can affect the cells ability to produce the required protein for its regular functions or provoke production of a toxic protein which would be fatal for the cells, thus, damaging the photoreceptor cells. RP can cause severe symptoms like night blindness, fundus appearance, tunnel vision, posterior subcapsular cataract that can eventually lead to blindness. RP has various subtypes, the most common subtype is a mutation in the gene coding for rhodopsin which affects 1 in 4000 patients. Some of these subtypes are caused due to mutations in genes coding for RPE, this can be potential targets for stem cell therapy to replace RPE [3, 13, 14].

\subsection{Stargardt's Disease}

Stargardt's disease is the most commonly inherited retinal disorder. Children are majorly affected by this retinal disorder with a prevalence of 1:8,000-10,000, arising during the first and second decades of life. The highly prevalent form, STGD1 is autosomal recessive in nature and occurs due to mutations in ABCA4 gene, that is responsible for encoding a transporter protein expressed on photoreceptors. The other forms like STGD3 and STGD4 are also caused due to mutations in ELOVL4 gene and PROM1 gene respectively where both of these genes code for proteins present in the PRs [3]. One of the symptoms presented by patients suffering from Stargardt's includes bilateral central vision loss with characteristic yellow-white flecks at the posterior edge of the RPE in the macular region which indicate buildup of lipofuscin in the PRs and later in the RPE. Currently, there is no treatment available for this disorder; research is being carried on to treat this disease with stem cell therapy, gene replacement therapy and various pharmacological approaches [15].

\subsection{Stem Cells to Treat Retinal and Corneal Disorders}

A mucosal epithelial overlying and underlying the eyelid is known as ocular surface [16]. In normal condition, the surface has three layers namely corneal, limbal and conjunctival epithelia, where every layer has a different cell type [17]. Corneal epithelial is made up of non-keratinised squamous epithelial cells; the property of this layer is to undergo a continuous custom of renewal and regeneration [16]. Stem cells present in these layers split and proliferate whenever there is a need for tissue repair. During splitting into two daughter cells, one cell retains the characteristic of rejuvenation while the other differentiate which is destined to be part of corneal epithelium also known as 'transient amplifying cells'. These cells are generally available at the basal layer of limbal and corneal epithelium [18].

Stem-cell deficiency can occur in case of chemical burns, SJS, aniridia, various endocrine deficiencies as it causes scarcity of stromal microenvironment to support stem cell function. Corneal cell deficiency can be identified by immunohistochemistry to detect any lack of corneal differentiated cells and an increase in goblet cells containing mucin $[16,19]$. Thus, Stem cell-based therapy should be an ideal treatment to treat blindness as it would have a low failure rate; it will not require immunosuppression and will be reproducible using a wide range of phenotypes. The sources for these cells include pluripotent as well as multipotent cells [3].

\section{UNDERSTANDING ROLE OF STEM CELLS IN OCULAR SURFACE DISORDERS}

\subsection{Role of Induced Pluripotent Stem Cells}

Reprogramming of mouse somatic cells by identification of essential transcription factors was first demonstrated by Takahashi and Yamanaka that urged the development of Induced Pluripotent Stem Cells (iPSCs) which have been used for various purposes, one of them being for the development of RPE cells [20]. Followed by this discovery, Yamanaka and colleagues succeeded in integrating transcription factors using retroviruses within human fibroblast cells to convert them into pluripotent stem cell-like state. With the successful conversion of hESCs into RPE, researchers used similar protocols for iPSCs obtained from prenatal and adult fibroblast to obtain RPE and retinal cells. These cells are evaluated based on common criteria that include; hexagonal cell morphology, observed pigmentation on cells, formation of cell polarity, tight junction formation and growth factor exudation [21]. The genetic profiles of these iPSCs are similar to ESCs but they do not have limitations similar to these cells i.e. ethical issues of embryo-derived cells and limited immune rejection as they are derived from the patient; making iPSCs a worthwhile opportunity for regenerative medicine. Various sources apart from human fibroblast can be used for cell derivation like NSCs, primordial blood cells and peripheral blood monocytes. Currently, Sendai viruses and episomal vectors are utilised to integrate the transcription factors to produce most of the iPSC cell lines [11].

The first clinical trial for AMD utilizing iPSCs was initially performed in Japan. The study was suspended within a year due to reported mutations in the derived iPSCs which were absent in the original patient fibroblast cells [11]. 
iPSCs, however, are considered to be comparable to hESCs as they have been shown to harbour differences in gene expression and DNA methylation. Chromosomal telomeres are observed to be significantly shorter in iPSCs compared to the native RPE indicating DNA aging. Thus, the cells might not have the desired lifespan, requiring one or more transplantations to attain effective results. Diseases like Stargardt's which occurs due to a single gene defect may prove to be a challenge for iPSC based therapies as the cells generated from the patient will contain the genetic defect. These defects need to be corrected prior to cell differentiation and transplantation. Whereas in AMD such genetic manipulations are not needed as it is a polygenic disease and no individual gene correction would be able to provide a cure [3].

Preparation of viable retinal precursor cells is vital for treating any disorders; patent CN103627669 defines a method for differentiation of human iPSCs into retinal precursor cells using a specific medium containing nitrogen followed by transfer to a neurogenic medium comprising knockout serum substitute as well as nicotinamide. The patent describes the morphological changes occurring within the cells in great detail making it easier for understanding. The cells can also be used for drug screening, treatment for AMD and gene interference experimentation (Table 1) [22]. Patent US 2015/0368713 A1 also describes a method for the production of high-efficiency RPE cells from induced somatic cells which also include fetal RPE cells. The patent initially references culturing of embryoid bodies on medium containing inhibitor for Nodal pathway and two inhibitors for Wnt pathway. The second medium has four variations wherein they lack fibroblast growth factors, Wnt and Nodal inhibitors, in addition to Noggin and knockout serum replacement. The cells are further cultured in selective medium to produce high-efficiency cells. Another embodiment mentions characterization of the cells and determining agents which affect the induced cells by increasing gene expression as well as help in RPE survival under stress (Table 1) [23]. Similarly, invention CN105274049 discloses a protocol for the culturing and differentiating of human iPSCs-3D retina cells to retinal ganglion cells. The patent is a first of its kind, providing methods and media formulations for directional differentiation of cells helping us understand as well as explore the regulatory mechanisms of iPSCs. These cells will not only be useful to treat major diseases specifically to treat optic nerve injury but also help to study tissue engineering of cells in the nervous tissue (Table 1) [24]. As these discoveries are in the infantile stages, the studies that are being carried out using humans are limited and have great scope for positive clinical trials.

Table 1. Summary of patents filed for iPSCs used for treating ocular disorders.

\begin{tabular}{|c|c|c|c|c|c|c|}
\hline No. & $\begin{array}{l}\text { Cell } \\
\text { Type }\end{array}$ & Patent No. & Disease & Summary & $\begin{array}{c}\text { Route of } \\
\text { Administration }\end{array}$ & Refs. \\
\hline 1 & iPSCs & CN103627669 & $\begin{array}{l}\text { Retinal neuronal } \\
\text { disorders } \\
\text { RP }\end{array}$ & $\begin{array}{l}\text { Method of inducing human pluripotent cells to obtain } \\
\text { retinal precursor cells like pigment epithelial precursor } \\
\text { cells and neurofilament progenitor cells. The invention } \\
\text { induces the cells with Neurobasal medium, knockout } \\
\text { serum replacement and nicotinamide so as to overcome } \\
\text { low differentiation efficiency and reduce the cell } \\
\text { differentiation time period. }\end{array}$ & - & {$[22]$} \\
\hline 2 & iPSCs & US2015/0368713A1 & $\begin{array}{l}\text { Retinal degenerative } \\
\text { disorders like AMD, } \\
\text { RP, Stargardt's } \\
\text { disease, Glaucoma } \\
\text { and diabetic } \\
\text { retinopathy }\end{array}$ & $\begin{array}{c}\text { Method to utilize iPSCs (somatic cells) to obtain retinal } \\
\text { pigment epithelium cells for their use in screening assays, } \\
\text { therapeutics with their pharmaceutical compositions } \\
\text { described in the invention and to study RPE. The iPSCs } \\
\text { are produced from somatic cells such as fetal retinal } \\
\text { pigment epithelial stem cells. }\end{array}$ & $\begin{array}{c}\text { Polymeric } \\
\text { scaffold/extracellular } \\
\text { matrix and cell } \\
\text { suspensions }\end{array}$ & {$[23]$} \\
\hline 3 & iPSCs & CN105274049 & $\begin{array}{l}\text { Treatment and } \\
\text { recuperation of optic } \\
\text { nerve injury }\end{array}$ & $\begin{array}{c}\text { The invention provides a procedure to induce directional } \\
\text { differentiation of iPSCs-derived 3D retinas into retinal } \\
\text { ganglion cells in vitro wherein a nerve cell layer is } \\
\text { digested into a single cell which is used as seed junction to } \\
\text { produce functional RGCs using various media } \\
\text { compositions. }\end{array}$ & - & {$[24]$} \\
\hline 4 & iPSC's & US20140127803A1 & $\begin{array}{l}\text { Bilateral Corneal } \\
\text { diseases }\end{array}$ & $\begin{array}{l}\text { This patent describes the procedure to transform induced } \\
\text { pluripotent stem cells to corneal epithelium cells in } \\
\text { presence of amniotic membrane. }\end{array}$ & - & {$[27]$} \\
\hline 5 & iPSC's & US20180010093A1 & $\begin{array}{l}\text { Damaged or diseased } \\
\text { ocular surface }\end{array}$ & $\begin{array}{l}\text { This invention relates to a method for inducing the } \\
\text { differentiation of corneal epithelial cells in serum-free } \\
\text { media from human pluripotent stem cells. }\end{array}$ & - & {$[28]$} \\
\hline 6 & iPSC's & WO2018037161A1 & Corneal diseases & $\begin{array}{l}\text { The patent describes methods to differentiate pluripotent } \\
\text { cells into corneal cells. }\end{array}$ & - & [29] \\
\hline
\end{tabular}

iPSCs are competent to individuate themselves into three layers namely, mesoderm, ectoderm and endoderm. This 
capability of iPSCs was first discovered in 2006 by the Nobel laureate Yamanaka since then its features has been used in various cell therapies including corneal surface disorders [25]. In in-vitro conditions, the pluripotent cells are immortal thus acting in favour of regenerative medicines [26].

Patent US 2014/012780A1 describes the method to form eye precursor cells from iPSCs. The inventors were able to grow iPSCs without the help of feeder cell layer. The cells were subjected to a medium which contained Bone Morphogenetic Protein - 4 (BMP-4), Tumour Growth Factor-Beta (TGF- $\beta$ ) inhibitor and Fibroblast Growth Factor (FGF). The culturing of the above cells in mentioned medium leads to the development of eye precursor cells. After this development, the cells were then grown in culture in absence of TGF- $\beta$, FGF and BMP-4 but in presence of Epidermal Growth Factor (EGF), hydrocortisone, insulin, isoproterenol, and tri-iodo-thyronine which aids in formation of corneal epithelial precursor cells and on maturation it forms corneal stratified epithelium cells (Table 1) [27]. In Osaka University, inventors were able to formulate a procedure by which these iPSCs were able to differentiate themselves into corneal epithelium stem cells. Pluripotent stem cells were exposed to the reprogramming factor in serum-free medium to acquire iPSCs which were able to differentiate themselves into corneal epithelial cells. The factors used in this medium were a stromal cell or amnion-derived cells. The cells which showed the presence of corneal epithelium cell surface marker having an inexhaustible life were selected. These selected cells can further be cultivated to form corneal epithelium sheet for the treatment of corneal surface disorders (Table 1) [28]. This invention guided the inventors to formulate a similar method to produce corneal epithelium cells. Here, the iPSCs were grown in a flask or a dish where substrate was made up of one or more elements. These elements were collagen, fibronectin, laminin or laminin fragments, vitronectin, basement membrane matrices, gelatin, hyaluronic acid, polylysine, vitronectin, and hyaluronic acid. Here, the media was like the earlier invention, a serum-free medium; however, this media did contain one or more of very minute amounts of BMP-4, TGF or activin. By this procedure, iPSCs formed a concentric zone of ectodermal lineages cells that contained eye precursor cells. To obtain only corneal epithelium cells from eye precursor cells, first, the cells were grown in media which consist of rock inhibitor, keratinocyte growth factor (KGF) and serum which gave corneal progenitor epithelium cells. These progenitor cells were screened for the presence of K12, pax6 and MUC16 markers on the cells that were selected for induction of corneal epithelium cells [29]. These corneal cells can be cultivated into sheet format which can then be incorporated into the defected eye surface as an alternative cell regenerative treatment in patients [28, 29].

\subsection{Role of Human Embryonic Stem Cells}

Human Embryonic Stem Cells (hESC) individuate into functional RPE by replicating with close morphology to endogenous tissue as well as acquiring cell surface markers specific to RPE. These cells display physiognomies, similar to the innate cells like polarity, phagocytosis, retinol cycling and similar tight junctions. Embryonic stem cells were used for the first time to restore visual function in Royal College of Surgeon rats; a widely used animal model to study disorders of the RPE as well as AMD, where embryonic stem cells derived from primates were used for replacement of RPE to treat AMD $[3,30]$. In humans, Schwartz et al. were the first to successfully transplant ESCs derived RPE into two patients suffering from varying forms of AMD and Stargardt's disease where no signs of graft rejection were observed within the first four months of transplantation. Further trials showed the long-term survival of a graft in 18 patients, the study demonstrated improved visual acuity and quality of life measure [9]. The efficiency of the protocols in use is limited for production of hESC. To improve these, 3D hydrogels have been used to culture the cells. The research indicated improved derivation of RPE from $0.5 \%$ RGD-alginate hydrogel. This type of hydrogel scaffold can also help in transport as well as transplantation of RPE and also help in the formation of neural tissue [31].

Human embryonic stem cells are produced using various methods; Patent WO2008/129554A1 describes a method for production of RPE cells from human stem cells majorly embryonic stem cells. The invention utilises Transforming Growth Factor- $\beta$ (TGF- $\beta$ ) superfamily for preparation of RPE. The cell culture system comprises a medium enhanced with TGF- $\beta$ superfamily, where the stem cells are promoted for directed or augmented differentiation. The patent provides a culture media comprising matured RPE, a method for harvesting these cells and for transplanting them into a subject to help treat retinal disorders due to loss of RPE or injury (Table 2) [32]. Similarly, Patent WO2009/051671A1 provides methods for production of RPE on a large scale from hESC and iPSCs using various media compositions like addition of growth factors along with methods for purification of the cultured RPE as well as to sub-culture these cells at various concentrations. The patent also gives a characterization of the cells and comparison of RPE with ones derived from other sources e.g. adult and fetal RPE. The invention also helps identify cell maturing agents which assist in various screening assays and the cells can also be used to treat various retinal disorders (Table 2) [33]. 
Table 2. Summary of patents filed for hESCs used for treating ocular disorders.

\begin{tabular}{|c|c|c|c|c|c|c|}
\hline No. & Cell Type & Patent No. & Disease & Summary & Route of Administration & Refs. \\
\hline 1 & hESCs & WO2008/129554A1 & $\begin{array}{l}\text { Retinal dysfunction, } \\
\text { injury or the loss of } \\
\text { retinal pigment } \\
\text { epithelium }\end{array}$ & $\begin{array}{l}\text { A process of differentiation of hESCs to RPE in a } \\
\text { basic medium consisting of various TGF } \beta \text { superfamily. } \\
\text { The patent claims method for RPE cell production in } \\
\text { bioreactors and further used to prepare therapeutic } \\
\text { compositions to treat retinal disorders. }\end{array}$ & Intraocular transplantation & {$[32]$} \\
\hline 2 & hESCs & WO2009/051671A1 & $\begin{array}{l}\text { AMD, Stargardt's } \\
\text { disease, } \quad \text { RP and } \\
\text { diabetic retinopathy }\end{array}$ & $\begin{array}{l}\text { The invention describes method to obtain a } \\
\text { substantially purified form of human RPE cells } \\
\text { induced from hESCs or other human stem cells. The } \\
\text { patent comprises of pharmaceutical compositions of } \\
\text { these RPE cells as well as cryopreserved preparation } \\
\text { thereof. The cells are also used for screening assays } \\
\text { based on the different markers like RPE-65, PEDF, } \\
\text { Otx2 etc.. The pharmaceutical compositions are further } \\
\text { used to treat retinal disorders. }\end{array}$ & $\begin{array}{l}\text { Intraocular transplantation } \\
\text { using suspension, matrix, } \\
\text { substrate or injection into } \\
\text { subretinal space of the eye }\end{array}$ & {$[33]$} \\
\hline 3 & hESCs & EP2484308 (A1) & $\begin{array}{lr}\text { Keratitis, } & \text { corneal } \\
\text { ulcer, } & \text { corneal } \\
\text { abrasion, } & \text { snow } \\
\text { blindness, } & \text { corneal } \\
\text { infections, } & \text { corneal } \\
\text { dystrophy } & \text { etc. }\end{array}$ & $\begin{array}{l}\text { The invention refers to a mode to obtain a } 3 \mathrm{D} \text { synthetic } \\
\text { cornea from parthenogenically activated human oocyte } \\
\text { followed by transplantation of the cornea to treat } \\
\text { various disorders as well as studying the effects of } \\
\text { therapeutic agents on the cornea. }\end{array}$ & $\begin{array}{l}\text { Implantation of synthetic } \\
\text { cornea }\end{array}$ & [35] \\
\hline 4 & $\begin{array}{l}\text { Human } \\
\text { placental } \\
\text { or human } \\
\text { umbilical } \\
\text { cells }\end{array}$ & US7412734B2 & $\begin{array}{lr}\text { Ocular degenerative } \\
\text { conditions } \\
\text { glaucoma, } & \text { RP, } \\
\text { nerve } & \text { trauma, } \\
\text { ocular lesions } & \text { etc. }\end{array}$ & $\begin{array}{l}\text { Method to utilise postpartum-derived cells for } \\
\text { differentiation into a neural cell fate which can further } \\
\text { be characterized based on the presence of cell surface } \\
\text { receptors. The neural cells are used to treat ocular } \\
\text { disorders and the patent also describes formulations as } \\
\text { well as routes of administrations thereof. }\end{array}$ & $\begin{array}{l}\text { Surface of the eye or } \\
\text { interior of the eye using a } \\
\text { cannula or device, } \\
\text { implantation using } \\
\text { scaffolds/extracellular } \\
\text { matrix containing cells }\end{array}$ & {$[36]$} \\
\hline 5 & hESCs & US2007/0031386A1 & $\begin{array}{|lr|}\text { AMD, RP and } \\
\text { related retinal } \\
\text { degenerative } \\
\text { disorders }\end{array}$ & $\begin{array}{l}\text { The invention provides a technique for derivation of } \\
\text { eye cells like neural, retinal, corneal cells etc. from } \\
\text { embryonic stem cells. The patent also embodies } \\
\text { characterization of the derived cells based in various } \\
\text { parameters followed by their used to treat various } \\
\text { retinal disorders as well as Parkinson's disease. }\end{array}$ & $\begin{array}{l}\text { Transplantation } \\
\text { subretinal space }\end{array}$ & {$[37]$} \\
\hline 6 & $\mathrm{hESC}$ & CN106754717A & 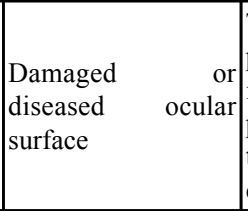 & $\begin{array}{l}\text { The invention provides an inducing culture medium to } \\
\text { produce corneal endothelial cells. The method does not } \\
\text { involve a feeder layer so that other animal origin } \\
\text { pollution is avoided, and the biological safety is high; } \\
\text { the corneal endothelial cells are used as corneal } \\
\text { endothelium seed cells in tissue engineering. }\end{array}$ & 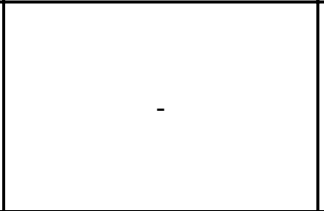 & {$[38]$} \\
\hline 7 & hESC & CN106167790A & $\begin{array}{lr}\text { Damaged } & \text { or } \\
\text { diseased } & \text { ocular } \\
\text { surface } & \end{array}$ & $\begin{array}{l}\text { This patent illustrates a method to induce the human } \\
\text { embryonic stem cells to differentiate into human neural } \\
\text { crest stem cells, inducing the human neural crest stem } \\
\text { cells to differentiate into the human corneal endothelial } \\
\text { cells. }\end{array}$ & - & [39] \\
\hline
\end{tabular}

The Patent US2007/0196919A1 describes a protocol for differentiation of hESC into retinal progenitor cells. These cells are multipotent i.e. they can give rise to neurons, photoreceptors etc. The cell population obtained after differentiation can be used for screening assays. These cells are allowed to transform in the presence of growth factors, bone morphogenetic protein, an antagonist to wnt signalling pathway and an IGF1R agonist to produce embryoid bodies. Genetic modifications are carried out to introduce traits useful for selection process like a selectable marker or can be used to improve the efficiency for tissue regeneration on transplantation. The patent also describes a kit with the cells and formulations for their optimal growth which can be cultured and used as grafts for treating glaucoma and AMD (Table 2) [34]. A procedure to develop synthetic cornea from hESCs has been described in patent EP2484308 (A1). The cornea obtained is 3D sensory scaffold transplantable in humans. The patent also mentions a protocol wherein the stem cells are obtained from human oocyte and differentiated with the help of a mitogen, bFGF or a combination of both. The invention further describes methods for treating as well as replacement for the cornea (Table 2) [35].

The Patent US7412734B2 refers to the derivation of retinal stem cells from human placental or umbilical cells which are cultured in L-valine rich medium. The patent also mentions methods for treatment for ocular disorders by providing a kit consisting of a pharmaceutical carrier, the cells as well as reagents for culturing the cells. The compositions given can be administered to the interior of an eye or to the surface (Table 2) [36]. Another invention 
US2007/0031386 A1 discussed methods for culturing RPE cells and their use for treatment thereof. The cells are characterized based on phenotyping, functionality, pluripotency of the cells based on transplantation in various animal models and the expression markers present on RPE. The invention describes a method of production of genetically modified trabecular meshwork to treat glaucoma along with methods to treat Parkinson's diseases with embryonic stem cells derived RPE (Table 2) [37].

Embryonic stem cells can be induced to differentiate into corneal epithelial cells by various techniques. Human embryonic stem cells can be differentiated into corneal endothelial cells in DMEM media without any feeder cells, avoiding any contamination of cells. In this DMEM media, mercaptoethanol, glutamine, basic FGF, Knockout Serum Replacement (KSR) and Retinoic Acid (RA) were added. Addition of RA in this culturing media was important as it directed human embryonic cells to form neural crest leading to corneal endothelium cells. The cells which showed similarities in human corneal cells were selected and expanded (Table 2) [38]. Embryonic stem cells can differentiate into corneal endothelial cells by first developing into neural crest stem cells. A procedure developed by Chinese inventor, cultivated human embryonic stem cells in a medium containing mouse embryonic cells as a feeder layer. Proliferative human embryonic stem cells were separated and then cultivated in human corneal stromal cells as another feeder layer, leading to the induction of human embryonic cells to neural crest cells. Induced neural crest cells were able to differentiate themselves into human corneal epithelial cells by utilising the described human corneal endothelium culture medium (Table 2) [39].

\subsection{Role of Mesenchymal Stem Cells to Treat Retinal Disorders}

Mesenchymal Stem Cells (MSCs) belong to the subtype of stromal cells which have the capacity for self-renewal as well as differentiation into multiple lineages [40]. They are derived from various tissues like umbilical tissue, embryonic mesoderm, bone marrow, adipose tissue, endometrial polyps [40, 41]. MSCs have the ability to clone into adherent fibroblast cells possessing unique cell surface receptors [41]. MSCs can differentiate into endoderm, mesoderm and ectoderm; under regulatory control of various transcription factors. Regulatory genes also help in differentiation of progenitor cells to specific lineage. MSCs have widely been cultured using various biomaterial scaffolds making them ideal candidates for stem cell-based therapies as patient autologous cells can be cultured [40]. Bone marrow-derived MSCs have been injected in the sub retinal cavity in mouse models of Retinitis Pigmentosa; these stem cells proved to be helpful as improvement of morphology was observed in the mice models [3]. Bone marrowderived MSCs were cultured from mice and targeted to differentiation into cells expressing markers for retinal cells (Holan et. al.). These cells were checked for anti-inflammatory effects as well as growth factor production. From the results, it was concluded that MSCs could support survival of the healthy cells within the diseased retinal cells by producing growth factors. Retinal damage is further associated with local inflammatory reactions which hinder wound healing, MSCs act by inhibiting production of cells causing inflammatory reactions mainly cytokines utilizing their immunosuppressive properties. MSCs are ideal for stem cell therapy due to their inherent ability to differentiate into various cell types; this diverging capacity was tested by incubating bone marrow-derived MSCs with retinal tissue extracts and cultures of stimulated spleen cells. The cultured MSCs expressed markers for retinal cells for e.g. Rhodopsin, Rlbp, Calb2 and S-antigen; making them quintessential for stem cell therapy for retinal disorders [42]. In another study bone marrow-derived, MSCs were used to treat patients suffering Retinitis Pigmentosa through intravitreal injection of the stem cells. The injection of the autologous cells did not meet safety standards and resulted into GFAP over expression, retinal folding, and detachment of the RPE and macrophage filtration. Thus further investigation needs to be carried out for use of the stem cells in humans [43].

The Patent US 20060280729A1 describes a method for treating ocular disorders using mesenchymal stem cells which are differentiated on the basis of surface markers specific to the retinal phenotype. The screening is done for cells expressing CD29, CD44, CD105 and CD166. Simultaneously, cells should also lack at least one of these markers; CD14, CD34 and CD45. These cells when transplanted at the target location they provide support for the cells and may differentiate into retinal cells with surface markers except rhodopsin and the cells do not form PR layers (Table 3) [44]. 
Table 3. Summary of patents filed for MSCs used for treating ocular disorders.

\begin{tabular}{|c|c|c|c|c|c|c|c|}
\hline No. & $\begin{array}{c}\text { Cell } \\
\text { Type }\end{array}$ & Patent No. & Disease & Summary & Trial Status & Route of Administration & Ref. \\
\hline 1 & MSCs & US20060280729A1 & $\begin{array}{lr} & \\
\text { Brain } & \text { trauma, } \\
\text { AMD, } & \text { RP, } \\
\text { optic } & \text { nerve } \\
\text { trauma, } & \\
\text { glaucoma } & \text { etc. }\end{array}$ & $\begin{array}{l}\text { Approach for treating patients by } \\
\text { administration of pharmaceutical } \\
\text { compositions of mesenchymal stem cells } \\
\text { that are characterized by the presence or } \\
\text { absence of surface markers wherein the } \\
\text { cells help survival in situ but do not have } \\
\text { similar structure as photoreceptor cells and } \\
\text { do not express markers specific to such } \\
\text { cells. }\end{array}$ & Pre-clinical & $\mid \begin{array}{lr}\text { Surface of the eye or interior of the } \\
\text { eye using a cannula or device, } \\
\text { implantation } & \text { using } \\
\text { scaffolds/extracellular } & \text { matrix } \\
\text { containing cells } & \end{array}$ & {$[44]$} \\
\hline
\end{tabular}

\subsection{Role of Adult Stem Cells}

Adult stem cells are characterised by their ability for self-renewal as well as the potential to differentiate into mature cells with specialized functions. Adult stem cells are rare and maintain cell homeostasis, replace wounded and dead cells. They are found in various tissues but their means of origin have not yet been identified, with the proposed theory that these cells are set aside during the differentiation phase during embryo development. Some tissues with reported adult stem cells are retina, cornea, bone marrow, peripheral blood. In this section, we discussed about hematopoietic stem cells and somatic stem cells both of which are classified as adult stem cells [45].

In patent WO2007/130060 A2, a method for isolation of adult retinal stem cells from extra-retinal ocular tissue has been described. These cells are isolated from vestigial tissue from a mammalian donor suffering from fatal vasculature. The patent further describes a method for treating retinal disorders using these retinal stem cells isolated from adult stem cells and a method for kit production for harvesting as well as culturing the extra-retinal ocular tissue (Table 4) $[46]$.

Table 4. Summary of patents filed for Adult Stem Cells used for treating ocular disorders.

\begin{tabular}{|c|c|c|c|c|c|c|c|}
\hline No. & $\begin{array}{l}\text { Cell } \\
\text { Type }\end{array}$ & Patent No. & Disease & Summary & Trial Status & $\begin{array}{c}\text { Route of } \\
\text { Administration }\end{array}$ & Refs. \\
\hline 1 & $\begin{array}{l}\text { Adult } \\
\text { stem } \\
\text { cells }\end{array}$ & $\begin{array}{c}\text { WO2007/130060 } \\
\text { A2 }\end{array}$ & 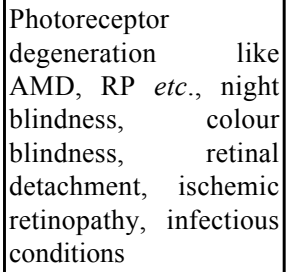 & $\begin{array}{l}\text { Methods for isolation of adult stem cells } \\
\text { from vestigial tissue of a donor suffering } \\
\text { from persistent fetal vasculature. The } \\
\text { invention further provides procedures to } \\
\text { culture these cells to obtain retinal stem } \\
\text { cells. The patent also offers a kit for } \\
\text { harvesting these extra-retinal ocular tissues } \\
\text { to improve survival rate. }\end{array}$ & Pre-clinical & $\begin{array}{l}\text { Injection or } \\
\text { transplantation of retinal } \\
\text { stem cells in retinal site, } \\
\text { subretinal space, vitreal } \\
\text { cavity, optic nerve using } \\
\text { a biodegradable carrier }\end{array}$ & {$[46]$} \\
\hline 2 & $\begin{array}{l}\text { Adult } \\
\text { stem } \\
\text { cells }\end{array}$ & CN102604886 (A) & $\begin{array}{l}\mathrm{AMD}, \mathrm{RP}, \text { diabetic } \\
\text { retinopathy }\end{array}$ & $\begin{array}{l}\text { Human somatic cells are used in the } \\
\text { presence of plant extracts and protein } \\
\text { inducible autologous retinal stem cells to } \\
\text { induce reverse differentiation to yield } \\
\text { retinal stem cells having similar markers to } \\
\text { retinal cells. }\end{array}$ & 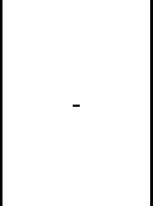 & - & {$[47]$} \\
\hline
\end{tabular}

Similarly, in patent CN102604886 (A) human body cells (blood mononuclear cells) are cultured in presence of plant extracts and proteins which induce reverse differentiation of these cells to autologous retinal stem cells and autologous retinal cells. The autologous retinal cells have similar markers as the retinal cells and differentiating abilities. The autologous stem cells can be used to treat various ocular disorders and the method described for the production of these cells can be possibly scaled up for large-scale industrial production. The invention also describes a method for kit production of these reverse differentiated cells (Table 4) [47].

\subsection{Hematopoietic Stem Cells}

Hematopoietic stem cells originating from the bone marrow are present in the ratio of 1:10,000-15,000. HSCs are capable of migrating through blood and are even found in fetal liver and spleen [2]. These cells are capable of forming blood vessels and are identified by the surface markers like CD34 ${ }^{+}$, Thy ${ }^{+}, \mathrm{Lin}^{-}$; as cells containing these markers are most likely stem cells and can be used for transplantation [2].

The Patent WO2004/01059 A2 describes a method to isolate lineage negative (Lin) hematopoietic stem cells 
containing endothelial progenitor cells (EPC) from adult bone marrow, upon transplantation these cells get incorporated into the vasculature and help in blood vessel formation, they additionally help in stabilizing retinal vasculature in diseased conditions like AMD and diabetic retinopathy. Further, in the study, they transfected the isolated Lin cells with a therapeutic gene of angiogenesis inhibiting peptides which prevented abnormal blood vessel formation in conditions like AMD and diabetic retinopathy (Table 5) [48].

Table 5. Summary of patents filed for hematopoietic stem cells used for treating ocular disorders.

\begin{tabular}{|c|c|c|c|c|c|c|c|}
\hline No. & Cell Type & Patent No. & Disease & Summary & $\begin{array}{l}\text { Trial } \\
\text { Status }\end{array}$ & Route of Administration & Refs. \\
\hline 1 & $\begin{array}{l}\text { Hematopoietic } \\
\text { stem cells }\end{array}$ & WO2004/01059A2 & \begin{tabular}{|l|} 
\\
Ocular vascular disease \\
e.g. AMD, diabetic \\
retinopathy
\end{tabular} & $\begin{array}{l}\text { Isolated bone-marrow derived } \\
\text { Lin hematopoietic stem cells } \\
\text { comprising endothelial } \\
\text { progenitor cells with markers } \\
\text { CD31 and c-kit that can be used } \\
\text { for development of retinal } \\
\text { vessels as well as prevent } \\
\text { degeneration of these vessels. } \\
\text { The cells are transfected with a } \\
\text { therapeutically beneficial gene } \\
\text { which specifically targets } \\
\text { neovasculature and inhibits new } \\
\text { retinal vessel formation acting } \\
\text { as a vasculotrophic and } \\
\text { neurotrophic agent. }\end{array}$ & Pre-clinical & Intravitreal injection & [48] \\
\hline 2 & $\begin{array}{l}\text { Hematopoietic } \\
\text { stem cells }\end{array}$ & US2010/0068141A1 & 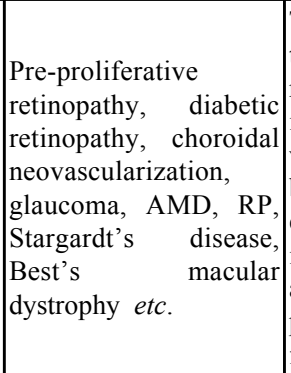 & $\begin{array}{l}\text { The patent claims a method for } \\
\text { treating ocular diseases } \\
\text { recruiting stem cells which are } \\
\text { induced by heat shock, within } \\
\text { which the heat shock is induced } \\
\text { by a small compound or an } \\
\text { expression vector. Further the } \\
\text { invention portrays modes of } \\
\text { administration r and } \\
\text { pharmaceutical compositions } \\
\text { for ameliorating ocular diseases. }\end{array}$ & Pre-clinical & \begin{tabular}{ll} 
Oral, rectal, & topical, \\
intraocular, & buccal, \\
intravaginal, intracisternal, \\
\multicolumn{2}{l}{ intracerebroventricular, } \\
intratracheal, & nasal, \\
transdermal, & \\
device/implants, & or \\
parenteral routes &
\end{tabular} & [49] \\
\hline
\end{tabular}

The Patent US 2010/0068141 A1 describes composition and methods useful for the treatment of various ocular disorders using hematopoietic stem cells, in a part of the patent they describe a method of recruiting HSC in the Retinal Pigment Epithelium (RPE) by subjecting them to sub-visible threshold lasers. These cells trans differentiate into RPE cells and express surface markers found on RPE. The study utilised GFP labelled HSC for transplantation and demonstrated the ability of HSC to migrate to the RPE. The laser-induced heat shock proteins, VEGF and stromal derived factor (SDF-1) helped the cells to acquire morphological features of RPE (Table 5) [49].

\subsection{Role of Neural Stem Cells}

Neural stem cells have a characteristic regenerative ability that gives rise to three cell types; neurons, astrocytes and oligodendrocytes. These cells give renewed hope for repair after injury or disease in the CNS [50]. The differentiation property of the particular cells is enhanced when they are cultured on a matrix or scaffold containing growth factors; the cells differentiate into neural stem cell-derived neurons which integrate at the site of implantation [2]. In a study in humans, neural retinal cells were transplanted to check for three major parameters; improvement in visual acuity, safety of the transplantation procedure and to check for rejection of the transplanted cells. Eight patients with RP and one with AMD received subretinal transplants out of which none experienced any postoperative side effects like retinal detachment, infection, retinal vasculitis, extensive bleeding or intraocular inflammation. This led the researchers to conclude, that the transplantation procedure is safe and indicated high graph tolerance but visual improvement was not observed in any of the nine patients [51]. In another study, neural stem cells derived from umbilical cord-derived mesenchymal stem cells were used for transplantation into the vitreous body of the rat models. It was observed that the transplanted cells reduced leakage in the retinal blood vessel demonstrating their ability to control endothelial cells and pericytes which may lead to improvement of microcirculation in diabetic retinopathy. The number of surviving retinal ganglion cells increased after transplantation and helped in curtailment of disease progression, promising for future treatment of neurodegenerative disorders using neural retinal cells [41]. 
The Patent US 2003/0207450 A1 reports a novel method for the isolation of neuroretina-derived retinal stem cells (NRSC) from human and murine models. These cells are isolated from the neuroretina region of the RPE possessing the potential for self-renewal and multipotent differentiation. On transplantation in diseased retina, these cells differentiated into photoreceptor cells making them true retinal cells and viable for treating various retinal disorders (Table 6) [52]. Similarly, in patent US 2003/0148513 A1, a novel method for isolating mammalian multipotent neural cells (MNSCs) is depicted. The invention describes method for isolating said cells from neural tissue and procedure for culturing these cells to form cluster of mammalian stem cells. Further, the invention provides pharmaceutical compositions and acceptable carriers useful for administering these cells for disease conditions and tissue regeneration (Table 6) [53].

Table 6. Summary of patents filed for Neural Stem Cells used for treating ocular disorders.

\begin{tabular}{|c|c|c|c|c|c|c|c|}
\hline No. & Cell Type & Patent No. & Disease & Summary & $\begin{array}{l}\text { Trial } \\
\text { Status }\end{array}$ & $\begin{array}{c}\text { Route of } \\
\text { Administration }\end{array}$ & Refs. \\
\hline 1 & \begin{tabular}{lll}
\multicolumn{3}{l}{ Neuroretina-derived } \\
Retinal & Stem & Cells \\
(NRSC) & &
\end{tabular} & US2003/0207450A 1 & Retinal dystrophy & $\begin{array}{l}\text { The patent explains a system for the } \\
\text { first successful isolation of stem cells } \\
\text { from neural retinal tissues which } \\
\text { have capability of self-renewal, } \\
\text { multipotency and retina-specific } \\
\text { differentiation. In one of the } \\
\text { embodiments, the neuroretinal tissue } \\
\text { from aged donors was also used for } \\
\text { stem cell production. }\end{array}$ & Pre-clinical & - & [52] \\
\hline 2 & $\begin{array}{ll}\text { Mammalian } & \\
\text { Multipotent } & \text { Neural } \\
\text { Stem Cells (MNSCs) }\end{array}$ & US2003/0148513A1 & \begin{tabular}{|lr} 
& \\
Disorders & affecting \\
vision & like, \\
neurodegenerative \\
disease, & autoimmune \\
disorder, & corporal \\
disease, & neurotoxic \\
disease, & \\
demyelinating & a \\
disorder & etc.
\end{tabular} & $\begin{array}{l}\text { The invention defines reagents and } \\
\text { methods used to produce neural stem } \\
\text { cells, to treat neurological and } \\
\text { corporal disorders. The art also } \\
\text { provides pharmaceutical } \\
\text { compositions which can be } \\
\text { administered to animal models to } \\
\text { check for effect and efficiency. For } \\
\text { production of retinal stem cells the } \\
\text { stem cells are cultured in a media } \\
\text { containing growth factors like TGF- } \\
\text { b3, CNTF and IGF-1 individually or } \\
\text { in combination which is used to treat } \\
\text { retinal defects. }\end{array}$ & Pre-clinical & $\begin{array}{l}\text { Injection to the } \\
\text { target site or } \\
\text { transplantation }\end{array}$ & {$[53]$} \\
\hline 3 & Neuroretinal Cells & US2011/0004304A1 & - & $\begin{array}{l}\text { The patent illustrates a bioreactor } \\
\text { comprising of three layers made of } \\
\text { microchannels, polymer scaffold and } \\
\text { thin film membrane embedded with } \\
\text { RPE cells used for culturing retinal } \\
\text { cells or tissues. The bioreactor layers } \\
\text { mimic the retinal structure and offer } \\
\text { spatial organization. }\end{array}$ & 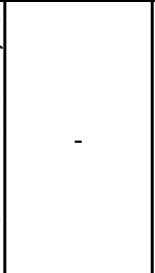 & - & [54] \\
\hline
\end{tabular}

The Patent US2011/0004304 A1 describes a bioreactor device consisting of three layers; first comprising of a network of micro channels, a polymer layer forming a scaffold and the final layer of a thin-film membrane impregnated with RPE which is sandwiched between the first two layers with the RPE facing the scaffold. The patent claims that neuroretinal cells can be cultured on these bioreactors composed of artificial plexus and micro structured scaffold. These bioreactors mimic layers of the retina and help in spatial organization. The scaffold also provides nutrients as well as oxygen which further helps in assembly of the cells seeded on the bioreactor (Table 6) [54].

\subsection{Role of Amniotic Membrane in Treating Corneal Disorders:}

Degeneration of eye, abnormalities or injuries like scarring can be jeopardy to a person's eyesight [55]. Ocular surface disorders are the second most leading cause of blindness [56], thus it is the need of hour to come up with innovative interventions. In conventional treatment, keratoplasty is conducted where healthy corneal epithelial cells are procured from either a healthy donor's eye or from the patient's eye itself and used as an auto graft or allograft respectively. The procurement of a large amount of healthy cells poses a risk to the eye from where they are secured [55].

In case of SJS, its primary stage shows a defect in conjunctiva and reduction in limbal stem cell deficiency. The described invention can help to treat this primary stage rather going to secondary stage. In this art, from an eye biopsy 
of the conjunctiva, cells were cultured wherein conjunctiva stem cells were isolated and expanded. The cells obtained from the biopsy were nurtured in a medium with human amniotic membrane as a substrate. During the period of cultivating conjunctiva cells, three types of media were used at various stages of isolation and expansion. However, hydrocortisone, Epidermal Growth Factor (EGF) and insulin were present in all three mediums. Various culturing steps were used to achieve well-characterised conjunctiva cells [57]. These could be transplanted to patient's eye by using Pterygium, Trabeculectomy and Seton surgery [58]. This invention was improvised by Devi et al in the year 2007, their methodology made it possible to cultivate conjunctival stem cells in one media rather three. The media used in this invention was Dulbecco's Modified Eagle's Media (DMEM) with 15\% nutrient serum addition and didn't require any feeder layer (Table 7) [57].

Table 7. Summary of patents filed for Corneal Epithelial stem cells used for treating ocular disorders.

\begin{tabular}{|c|c|c|c|c|c|c|}
\hline No. & Cell Type & Patent No. & Disease & Summary & $\begin{array}{c}\text { Route of } \\
\text { Administration }\end{array}$ & Refs. \\
\hline 1 & $\begin{array}{l}\text { Corneal Epithelial } \\
\text { stem cells }\end{array}$ & US20020039788A1 & $\begin{array}{l}\text { Damaged or diseased } \\
\text { ocular surface }\end{array}$ & $\begin{array}{l}\text { This patent describes the methods to form a } \\
\text { bioengineered corneal epithelial composite graft } \\
\text { on an extracellular matrix. This graft can aid in } \\
\text { the treatment of damaged ocular } \\
\text { surface especially corneal epithelium. }\end{array}$ & $\begin{array}{l}\text { Implantation to the } \\
\text { target site. }\end{array}$ & [55] \\
\hline 2 & $\begin{array}{l}\text { Conjunctival stem } \\
\text { cells }\end{array}$ & US20070218039A1 & $\begin{array}{l}\text { Damaged or diseased } \\
\text { ocular surface }\end{array}$ & $\begin{array}{l}\text { The patent characterise a method where with the } \\
\text { help of a simple single medium culture scheme, } \\
\text { and a support material a tissue system is formed } \\
\text { which is transplanted to the diseased or } \\
\text { damaged ocular surface. }\end{array}$ & $\begin{array}{l}\text { Implantation } \\
\text { target site. }\end{array}$ & [57] \\
\hline 3 & $\begin{array}{l}\text { Corneal } \\
\text { Endothelial cells } \\
\text { with amniotic } \\
\text { membrane }\end{array}$ & US2005O214259A1 & \begin{tabular}{|lr|}
\multicolumn{2}{|l}{ Corneal edema, } \\
keratoleukoma \\
keratoconus.
\end{tabular} & $\begin{array}{l}\text { Corneal endothelial cells were harvested, } \\
\text { multiplied and grown on a collagen layer } \\
\text { (amniotic membrane) to form corneal } \\
\text { endothelium-like sheet. }\end{array}$ & $\begin{array}{l}\text { Implantation to the } \\
\text { target site. }\end{array}$ & [59] \\
\hline
\end{tabular}

Patent US 2007/0218039A1 demonstrated isolation of corneal epithelium cells from a healthy eye. A biopsy was conducted on the healthy eye at the limbus region. The cells found in this region were epithelium cells; possessing several stem cell-like properties. To cultivate these cells, the tissue from biopsy was cultured in DMEM containing glutamine, foetal calf serum, hydrocortisone, EGF, ABAM and cholera toxin. The corneal cells were placed on 3T3 feeder cells; upon colony formation in this medium, the cells were transferred to new serum-free medium in absence of feeder cells, which contained Keratinocyte Growth Factor (KGF) and low calcium for expansion of the cells. These cells were transferred to an Extracellular Matrix (ECM) made up of fresh human amniotic membrane. Once the cells grow on this ECM, they are processed with either growth factor or one attachment factor like hydrocortisone, KGF, fibrin, collagen, laminin, EGF and hepatocyte growth factor. This selection made sure that a multi-layered polarity of corneal cells was nurtured. $\mathrm{H}$ and $\mathrm{E}$, immunocytochemical staining was organized to ensure that the cells adhered were corneal epithelium cells. This composite graft was then applicable to use in keratoplasty surgery (Table 7) [55].

Similar to patent US 2007/0218039A1, another invention by US 2005/O214259A1 was able to cultivate a corneal epithelium-like sheet on an ECM made up of amniotic membrane and collagen. This invention made it possible to treat ocular disorders which required corneal epithelium transplantation (Table 7) [59].

A retrospective study by Koizumi et al., in 11 patients suffering from severe stem cell deficiency due to SJS; underwent transplantation of corneal epithelial cells with an amniotic membrane as a carrier. Within 48 hours, no epithelial defects were observed suggesting that the complete transplantation took place. After 6 months of transplantation, the patients showed progressive clear vision indicating that amniotic membrane can be used as ECM for successful graft transplantation [60].

\subsection{Use of Cultured stem Cells in Various Devices}

In ocular surface disorders, corneal scarring causes inability of corneal epithelial cell to regenerate causing opaqueness of the eye steering to hindrance in proper vision. To improve such disrupted vision, several devices and hydrogels are being invented.

One such device promises to improve vision by corneal overlay. In this invention, corneal epithelial cells or limbal stem cells are extracted from the patient itself, which will require the corneal appliance. This reduces graft rejection and toxic reactions along with the stem cells, small portion of corneal epithelium is taken leaving out Bowman's membrane or stroma of the cornea. The appliance consists of lens and epithelial cells fixed on the lens forming a layer or a flap. 
This contact lens can be made of synthetic stroma having desired power, toric lens or by using hydrogels. This ocular device is then placed on the affected area of cornea which then aids in improving the visual acuity (Table 8) [61].

The main cause in disruption of cornea is epithelial dysfunction, wherein the tissue layer of cornea is intact but there are some voids in the cell layer. To treat this condition, a system is invented where the healthy cells are delivered to these voids. The system consists of a biodegradable film made up of biopolymer which is suitable for the eye as well as supports and initiates expansion of healthy epithelial cells placed on it. The corneal epithelial cells used for transplantation are extracted from a healthy part of patient's eye in a small amount. These cells are then cultured, following placement on the film. The complete film is placed on the patient's cornea where the film acts as a transport system to deliver healthy epithelial cells. Once the film is fixed, it dissolves over time leaving behind only healthy functional cell layer over the cornea, completing the cell replacement therapy (Table 8) [62].

For corneal injury treatment, few Chinese inventors have developed a biological cornea patch. This cornea patch was composed of silk protein layered with human bone marrow mesenchymal stem cells. The patch with a good amount of seeded stem cells was grafted on damaged cornea for treatment of injury (refer Table 8) [63]. Another method to transport healthy corneal stem cells to the wounded and injured ocular surface is by using hydrogels. In an invention, the hydrogel consists of 1.1-1.3\% strontium alginate which is in thin layer or disc-shaped. These hydrogels contain encapsulated healthy human corneal stem cells in water-soluble pore which is directly applied on the site of ocular surface injury for transporting healthy cells and forming its layer for treatment (Table 8) [64]. Using this same hydrogel concept, baiji sulfated Bletilla striata polysaccharide can also be used to treat ocular damage. Umbilical cord mesenchymal stem cells of passage 3 to passage 5 were infused into polysaccharide of density $1 \times 10^{5}$ to $5 \times 10^{5}$ number of cells/ ml. This combination of cells and polysaccharide promoted the mesenchymal cells to differentiate and proliferate into corneal epithelial cells. Thus, this preparation has competence to repair ocular surface damage (Table 8) [65].

Table 8. Summary of patents filed for Limbal Stem Cells used for treating ocular disorders.

\begin{tabular}{|c|c|c|c|c|c|c|}
\hline No. & Cell Type & Patent No. & Disease & Summary & $\begin{array}{c}\text { Route of } \\
\text { Administration }\end{array}$ & Refs. \\
\hline 1 & $\begin{array}{l}\text { Limbal } \quad \text { Stem } \\
\text { Cells }\end{array}$ & US20050080484A1 & $\begin{array}{l}\text { De-epithelialized } \\
\text { Cornea }\end{array}$ & $\begin{array}{l}\text { Invention of corneal appliance is explained here. } \\
\text { Wherein the lens body consists of endothelial } \\
\text { cells procured from limbal stem cells. }\end{array}$ & $\begin{array}{l}\text { Implantation to the } \\
\text { target site. }\end{array}$ & {$[61]$} \\
\hline 2 & $\begin{array}{l}\text { Corneal } \\
\text { endothelial cells }\end{array}$ & US20090222086A1 & $\begin{array}{l}\text { Corneal endothelial } \\
\text { defects and disorders }\end{array}$ & $\begin{array}{l}\text { The invention provides a resolvable corneal } \\
\text { button comprised of a biodegradable polymer } \\
\text { which is capable of supporting the growth and } \\
\text { expansion of endothelial cells on its surface for } \\
\text { use in transplantation of healthy corneal } \\
\text { endothelial cells to cornea tissue in need of a } \\
\text { transplant and a method of using same. }\end{array}$ & $\begin{array}{l}\text { Implantation to the } \\
\text { target site. }\end{array}$ & {$[62]$} \\
\hline 3 & $\begin{array}{l}\text { Mesenchymal } \\
\text { Stem Cells }\end{array}$ & CN104941001A & $\begin{array}{lr}\text { Ocular } & \text { surface disorder } \\
\text { like } & \text { ophthalmology } \\
\text { blinding } & \text { corneal } \\
\text { ulcers }\end{array}$ & $\begin{array}{l}\text { In this patent, bone mesenchymal stem cells } \\
\text { which are derived from allograft are planted on a } \\
\text { silk protein biological film to develop the } \\
\text { corneal patch used for curing corneal injuries; } \\
\text { such as corneal ulcer. }\end{array}$ & $\begin{array}{l}\text { Implantation to the } \\
\text { target site. }\end{array}$ & {$[63]$} \\
\hline 4 & $\begin{array}{lr}\text { Corneal } & \text { stem } \\
\text { cells, MSC } & \text { or } \\
\text { ESC } & \end{array}$ & US20140072601A1 & $\begin{array}{l}\text { Damaged or diseased } \\
\text { ocular surface }\end{array}$ & $\begin{array}{l}\text { The patent describes a hydrogel prepared } \\
\text { encapsulating live cells like corneal stem cells, } \\
\text { mesenchymal stem cells or embryonic stem } \\
\text { cells. }\end{array}$ & $\begin{array}{l}\text { Topical application at } \\
\text { the target site. }\end{array}$ & {$[64]$} \\
\hline 5 & $\begin{array}{l}\text { Umbilical cord } \\
\text { MSC }\end{array}$ & CN105147722A & $\begin{array}{l}\text { Damaged or diseased } \\
\text { ocular surface }\end{array}$ & $\begin{array}{l}\text { This patent talks about a preparation containing } \\
\text { sulphated Bletilla Striata polysaccharide and } \\
\text { umbilical cord mesenchymal stem cells used for } \\
\text { remarkably promoting the reproduction of } \\
\text { corneal epithelial cells }\end{array}$ & $\begin{array}{l}\text { Topical application at } \\
\text { the target site. }\end{array}$ & {$[65]$} \\
\hline 6 & $\begin{array}{l}\text { Mesenchymal } \\
\text { stem cell }\end{array}$ & CN107412266A & $\begin{array}{l}\text { Conjunctival } \\
\text { Corneal ulcers }\end{array}$ & $\begin{array}{l}\text { Invention of small pet eye drops made up of } \\
\text { mesenchymal stem cells that can promote } \\
\text { production of corneal epithelial cells on its } \\
\text { application. }\end{array}$ & $\begin{array}{l}\text { Eye drops applied at } \\
\text { the target site. }\end{array}$ & {$[66]$} \\
\hline 7 & $\begin{array}{l}\text { Living endothelial } \\
\text { cells }\end{array}$ & US20100274257A1 & $\begin{array}{l}\text { Damaged or diseased } \\
\text { ocular surface }\end{array}$ & $\begin{array}{l}\text { This corneal endothelial tissue inserter associates } \\
\text { to a medical device that works with eye tissue } \\
\text { which retracts an extremely thin layer of donor } \\
\text { endothelial eye tissue and places this tissue } \\
\text { within the eye of a recipient. }\end{array}$ & $\begin{array}{l}\text { Device acts like an } \\
\text { Injection }\end{array}$ & {$[67]$} \\
\hline
\end{tabular}


In-vitro cultivation of umbilical cord mesenchymal stem cells can be incorporated into pet eyes drop. These stem cells releases cytokines, which helps the healthy corneal endothelial cells present in damage cornea to proliferate, and heal the wound, making it an easy drug delivery system (Table 8) [66]. Cultured healthy corneal endothelial cells can be transferred to wounded cornea without any trauma or minimal trauma by using a device created by American inventors. This device has a longitudinal irrigation tube which is placed inside a handle. At one end it has a button where the handle is wider and on the end of the handle, it has a tapered nose. From this tapered nose, a forward tube is projected outward. The irrigation tube and forward tube consist of epithelial cells which are delivered to the damaged cornea by the surgeon by pressing the button on top of the handle (Table 8) [67].

\section{CONCLUSION AND FUTURE PROSPECTS}

Ocular surface disorders are tormenting and lead to visual impairment. Stem cell transplantation for ocular diseases is currently progressing from over a decade of preclinical to the early stages of clinical trials. The review describes many patents wherein the method of culturing and obtaining these cells has been given and formulations for their use in tissue regeneration as well as treating retinal disorders with different approaches have been described. More studies need to be carried out to observe the immune response on transplantation as well as clinical trials need to be conducted to test these formulations and their efficacy [3]. Regularizing the different parameters between patients and stem cell transplantation is difficult to accomplish. However, if in the next ten years, studies conducted by numerous researchers, patients treated and results published of this work will help the field to be generally accepted as a conventional method to treat ocular surface disorder.

Another important aspect to be addressed is the cost to benefit ratio of these studies as culturing of these grafts is an expensive affair wherein in the future when these grafts will be commercially produced they might not be profitable to these organizations as this form of treatment is not affordable for all patients. In countries with publicly funded healthcare systems, the process of graft generation has a high cost-benefit ratio. Thus, major work needs to be carried out to not only successfully use of stem cells to treat ocular disorders but also to make this form of therapy a conventional one which would be affordable to all patients [68].

\section{CONSENT FOR PUBLICATION}

Not applicable.

\section{CONFLICT OF INTEREST}

The authors declare no conflict of interest, financial or otherwise.

\section{ACKNOWLEDGEMENTS}

Declared none.

\section{REFERENCES}

[1] Blindness: World Health Organization website. Available at: http://www.who.int/blindness/causes/en/ (Accessed on: 23/05/2017).

[2] Mead B, Berry M, Logan A, Scott RA, Leadbeater W, Scheven BA. Stem cell treatment of degenerative eye disease. Stem Cell Res (Amst) 2015; 14(3): 243-57. [http://dx.doi.org/10.1016/j.scr.2015.02.003] [PMID: 25752437]

[3] Ramsden CM, Powner MB, Carr AJ, Smart MJ, da Cruz L, Coffey PJ. Stem cells in retinal regeneration: Past, present and future. Development 2013; 140(12): 2576-85.

[http://dx.doi.org/10.1242/dev.092270] [PMID: 23715550]

[4] Baylis O, Figueiredo F, Henein C, Lako M, Ahmad S. 13 years of cultured limbal epithelial cell therapy: A review of the outcomes. J Cell Biochem 2011; 112(4): 993-1002.

[http://dx.doi.org/10.1002/jcb.23028] [PMID: 21308743]

[5] Daniels JT, Dart JK, Tuft SJ, Khaw PT. Corneal stem cells in review. Wound Repair Regen 2001; 9(6): $483-94$. [http://dx.doi.org/10.1046/j.1524-475x.2001.00483.x] [PMID: 11896990]

[6] Shaheen BS, Bakir M, Jain S. Corneal nerves in health and disease. Surv Ophthalmol 2014; 59(3): $263-85$. [http://dx.doi.org/10.1016/j.survophthal.2013.09.002] [PMID: 24461367]

[7] White ML, Chodosh J, Jang J, Dohlman C. Incidence of Stevens-Johnson syndrome and chemical burns to the eye. Cornea 2015; 34(12): $1527-33$.

[http://dx.doi.org/10.1097/ICO.0000000000000646] [PMID: 26488629] 
[8] Oliva MS, Schottman T, Gulati M. Turning the tide of corneal blindness. Indian J Ophthalmol 2012; 60(5): $423-7$. [http://dx.doi.org/10.4103/0301-4738.100540] [PMID: 22944753]

[9] Garg A, Yang J, Lee W, Tsang SH. Stem cell therapies in retinal disorders. Cells 2017; 6(1): 4. [http://dx.doi.org/10.3390/cells6010004] [PMID: 28157165]

[10] Bahadorani S, Singer M. Recent advances in the management and understanding of macular degeneration. F1000 Res $2017 ; 6$ : 519. [http://dx.doi.org/10.12688/f1000research.10998.1] [PMID: 28491291]

[11] Parameswaran S, Krishnakumar S. Pluripotent stem cells: A therapeutic source for age-related macular degeneration. Indian J Ophthalmol 2017; 65(3): 177-83. [http://dx.doi.org/10.4103/ijo.IJO_1026_15] [PMID: 28440245]

[12] Mandai M, Watanabe A, Kurimoto Y, et al. Autologous induced stem-cell-derived retinal cells for macular degeneration. N Engl J Med 2017; 376(11): 1038-46. [http://dx.doi.org/10.1056/NEJMoa1608368] [PMID: 28296613]

[13] Fahim AT, Daiger SP, Weleber RG. Nonsyndromic retinitis pigmentosa overview. In: Pagon RA, Adam MP, Ardinger HH, Eds. GeneReviews ${ }^{\circledR}$. Seattle, WA: University of Washington, Seattle 2000; pp. 1993-2017.

[14] Retinitis Pigmentosa (RP). 2017. PubMed Health. Available on: https:/www.ncbi.nlm.nih.gov/pubmedhealth/PMHT0024256/

[15] Tanna P, Strauss RW, Fujinami K, Michaelides M. Stargardt disease: Clinical features, molecular genetics, animal models and therapeutic options. Br J Ophthalmol 2016.

[16] Dua HS, Saini JS, Azuara-Blanco A, Gupta P. Limbal stem cell deficiency: Concept, aetiology, clinical presentation, diagnosis and management. Indian J Ophthalmol 2000; 48(2): 83-92. [PMID: 11116520]

[17] Chen JJ, Tseng SC. Corneal epithelial wound healing in partial limbal deficiency. Invest Ophthalmol Vis Sci 1990; 31(7): 1301-14 [PMID: 1694836]

[18] Kruse FE. Stem cells and corneal epithelial regeneration. Eye (Lond) 1994; 8(Pt 2): 170-83. [http://dx.doi.org/10.1038/eye.1994.42] [PMID: 7958018]

[19] Dua HS, Forrester JV. The corneoscleral limbus in human corneal epithelial wound healing. Am J Ophthalmol 1990; 110(6): 646-56. [http://dx.doi.org/10.1016/S0002-9394(14)77062-X] [PMID: 2248329]

[20] Takahashi K, Yamanaka S. Induction of pluripotent stem cells from mouse embryonic and adult fibroblast cultures by defined factors. cell 2006; 126(4): 663-76. Aug 25

[21] Wright LS, Phillips MJ, Pinilla I, Hei D, Gamm DM. Induced pluripotent stem cells as custom therapeutics for retinal repair: Progress and rationale. Exp Eye Res 2014; 123: 161-72. [http://dx.doi.org/10.1016/j.exer.2013.12.001] [PMID: 24534198]

[22] Wang Xiaobing, Zhou Guomin. Method used for inducing differentiation of human multipotential stem cells into retinal progenitor cells. 2014. CN103627669

[23] Bharti K, Davis J, Maminishkis A, Ferrer-Alegre M, Miller SS. Method for generating retinal pigment epithelium (rpe) cells from Induced Pluripotent Stem Cells (iPSCs). US 2015/0368713 A1 (2015).

[24] Jian G, Zhong X. Method for directionally differentiating human iPSCs (Induced Pluripotent Stem Cells)-derived 3D (three-dimensional) retinas by means of induction to obtain retinal ganglion cells. CN105274049 (2016).

[25] Wilson KD, Wu JC. Induced pluripotent stem cells. JAMA 2015; 313(16): 1613-4. [http://dx.doi.org/10.1001/jama.2015.1846] [PMID: 25919522]

[26] Trounson A, DeWitt ND. Pluripotent stem cells progressing to the clinic. Nat Rev Mol Cell Biol 2016; 17(3): 194-200. [http://dx.doi.org/10.1038/nrm.2016.10] [PMID: 26908143]

[27] Hayashi R. iPS cell having differentiation propensity for corneal epithelium. US20140127803A1 (2011).

[28] Nishida K, Hayashi R, Ishikawa Y. Method for inducing differentiation of corneal epithelial cells from pluripotent stem cells. US20180010093A1 (2015).

[29] Ilmarinen T, Hongisto H, Skottman H, Mikhailova A. Differentiation of pluripotent stem cells into corneal cells. WO2018037161A1 (2016).

[30] Mazzilli JL, Domozhirov AY, Mueller-Ortiz SL, Garcia CA, Wetsel RA, Zsigmond EM. Derivation and characterization of the human embryonic stem cell line CR-4: Differentiation to human retinal pigment epithelial cells. Stem Cell Res (Amst) 2017; $18: 37-40$. [http://dx.doi.org/10.1016/j.scr.2016.12.005] [PMID: 28395800]

[31] Hunt NC, Hallam D, Karimi A, et al. 3D culture of human pluripotent stem cells in RGD-alginate hydrogel improves retinal tissue development. Acta Biomater 2017; 49: 329-43. [http://dx.doi.org/10.1016/j.actbio.2016.11.016] [PMID: 27826002]

[32] Idelson M. Stem cell-derived retinal pigment epithelial cells. WO2008/129554A1 (2008).

[33] Malcuit C, Lemieux L, Holmes W, Huertas P, Vilner L. Improved methods of producing rpe cells and compositions of RPE cells. WO2009/051671A1 (2009). 
[34] Reh T. Method of generating human retinal progenitors from embryonic stem cells. US2007/0196919A1 (2007).

[35] Hammond J, Kelleher-Andersson J. Synthetic cornea from retinal stem cells. E 2012; (A1): 2484308.

[36] Mistry S. Treatment of retinitis pigmentosa. with human umbilical cord cells. US 7,413,734 B2 (2008).

[37] Irina V. Modalities for the treatment of degenerative diseases of the retina. US 2007/0031386 A1 (2007).

[38] Zhou Q, Duan H. Method for inducing embryonic stem cell to be differentiated into corneal endothelial cells and inducing culture medium. CN106754717A (2016).

[39] Chen X, Wu L. A directional differentiation induction method of human embryonic stem cells to obtain corneal endothelial cells. CN106167790A (2016).

[40] Ding DC, Shyu WC, Lin SZ. Mesenchymal stem cells. Cell Transplant 2011; 20(1): 5-14. [http://dx.doi.org/10.3727/096368910X] [PMID: 21396235]

[41] Zhang W, Wang Y, Kong J, Dong M, Duan H, Chen S. Therapeutic efficacy of neural stem cells originating from umbilical cord-derived mesenchymal stem cells in diabetic retinopathy. Sci Rep 2017; 7(1): 408 [http://dx.doi.org/10.1038/s41598-017-00298-2] [PMID: 28341839]

[42] Holan V, Hermankova B, Kossl J. Perspectives of stem cell-based therapy for age-related retinal degenerative diseases. Cell Transplant 2017; 26(9): 1538-41. [http://dx.doi.org/10.1177/0963689717721227] [PMID: 29113466]

[43] Satarian L, Nourinia R, Safi S, et al. Intravitreal injection of bone marrow mesenchymal stem cells in patients with advanced retinitis pigmentosa; a safety study. J Ophthalmic Vis Res 2017; 12(1): 58-64. [http://dx.doi.org/10.4103/2008-322X.200164] [PMID: 28299008]

[44] Mistry S. Cellular therapy for ocular degeneration. US 2006/0280729 A1 (2006).

[45] National Research Council (US) and Institute of Medicine. Stem Cells and the future of regenerative medicine. Washington (DC): National Academies Press (US); 2002. CHAPTER TWO, Adult Stem Cells.

[46] Lashkari K, Shatos M. Isolation and therapeutic application of adult retinal stem cells collected from extra-retinal tissues 2007; WO2007(130060): A2.

[47] Lin X, Shi H. Method for generating autologous retinal stem cells and autologous retinal cells by reversely differentiating human body cells, kit and application of autologous retinal stem cells and autologous retinal cells. CN102604886 (A) (2012).

[48] Friedlander M, Otani A, DaSilva K. Hematopoietic stem cells and methods of treatment of neovascular eye diseases therewith 2004; WO2004(01059): A2.

[49] Kaushal S. Use of heat shock to treat ocular disease. US 2010/0068141 A1 (2010).

[50] Kornblum HI. Introduction to neural stem cells. Stroke 2007; 38(2)(Suppl.): 810-6. [http://dx.doi.org/10.1161/01.STR.0000255757.12198.0f] [PMID: 17261745]

[51] Humayun MS, de Juan E Jr, del Cerro M, et al. Human neural retinal transplantation. Invest Ophthalmol Vis Sci 2000; 41(10): 3100-6. [PMID: 10967070]

[52] Young MJ, Klassen HJ, Shatos MA, Mizumoto K. Isolation and transplantation of retinal stem cells US 2003; 2003/0207450: A1.

[53] Sugaya K, Qu T, Pulido J S. Novel mammalian multipotent neural stem cells and compositions, methods of preparation and methods of administration thereof. US 2003/0148513 A1 (2003).

[54] Tao SL, Redenti S, Sodha S, Borenstein JT, Young M. Culturing retinal cells and tissues 2011; US2011(0004304): A1.

[55] Roslyn R, Ivan R. Corneal epithelial graft composites. US20020039788A1 (2002).

[56] Daniels JT, Dart JK, Tuft SJ, Khaw PT. Corneal stem cells in review. Wound Repair Regen 2001; 9(6): $483-94$. [http://dx.doi.org/10.1046/j.1524-475x.2001.00483.x] [PMID: 11896990]

[57] Devi KS, Reddy K, Vasania V. Conjunctival tissue system. US20070218039A1 (2007).

[58] James A. Apparatus and method for non-pharmacological treatment of glaucoma and lowering intraocular pressure. US20050283108A1 (2005).

[59] Sano Y, Kinoshita S. Corneal endothelium-like sheet (86) pct no.: pct/p03/01515 and method of constructing the same. US2005O214259A1 (2003).

[60] Koizumi N, Inatomi T, Suzuki T, Sotozono C, Kinoshita S. Cultivated corneal epithelial stem cell transplantation in ocular surface disorders. Ophthalmology 2001; 108(9): 1569-74.

[http://dx.doi.org/10.1016/S0161-6420(01)00694-7] [PMID: 11535452]

[61] Marmo J. Devices and methods for improving vision. US20050080484A1 (2002).

[62] Lui GM, Lee A, Dong S, Wuh H. Resorbable cornea button. US20090222086A1 (2005).

[63] Xuan Z, Wang Y. Biological film corneal patch and preparation method and application thereof. CN104941001A (2015). 
[64] Connon CJ, Cave RA, Khutoryanskiy V, Wright B. Transport of cells in hydrogels. US20140072601A1 (2014).

[65] Ge X, Chen H. Novel application of sulfated bletilla striata polysaccharide and preparation for treating ocular surface damage. CN105147722A. (2015).

[66] Zhen Q, Lu Z. Small pet eye drops containing human mesenchymal stem cell excreta and preparation method thereof. CN107412266A (2017).

[67] William B. Corneal endothelial tissue inserter. US20100274257A1 (2007).

[68] Watt FM, Driskell RR. The therapeutic potential of stem cells. Philos Trans R Soc Lond B Biol Sci 2010; 365(1537): 155-63. [http://dx.doi.org/10.1098/rstb.2009.0149] [PMID: 20008393]

\section{(C) 2018 Chatterji et al.}

This is an open access article distributed under the terms of the Creative Commons Attribution 4.0 International Public License (CC-BY 4.0), a copy of which is available at: https://creativecommons.org/licenses/by/4.0/legalcode. This license permits unrestricted use, distribution, and reproduction in any medium, provided the original author and source are credited. 